\title{
Low rank coal drying technology for decreasing electricity cost production: case study of Nagan Raya power plant
}

\author{
Agus Setiawan ${ }^{1}$, Zainal Arifin ${ }^{1,2, *}$ \\ Technology Development and Standardization Department, PLN, Jakarta, Indonesia ${ }^{1}$ \\ Energy and Power Department, Institut Teknologi PLN, Jakarta, Indonesia ${ }^{2}$
}

\begin{abstract}
Considering the depletion of black coal resources, utilization of low rank coal currently is emerging to meet the growing of electricity consumption globally. Some coal fired power plants urge to use the domestic low rank coal due to some financial reasons. They are several coal drying technologies have been proposed. This study analyzes the utilization low rank coal to decrease the electricity cost production at Nagan Raya coal fired power plant. The Coal Moisture Control Fluidized Bed (CMC-FB) technology is selected as a basis for both technical and financial calculation. Based on the pilot project in Fukuoka, this technology is technically feasible and well suited for Nagan Raya power plant. A financial modelling shows that coal drying technology implementation can potentially decrease the electricity cost production for the utility and also make benefits for the investor. Further research is recommended to investigate other proven technologies. Additionally the effect of coal drying implementation to the environment should be noticed.
\end{abstract}

\section{Introduction}

Nowadays with the depletion of black coal reserves, the low rank brown coal is much more needed to meet the ever-growing demand of energy especially in electricity[1]. In many cases there are still many low rank coal which is used to produce electricity around the world. Lignite coal is the single largest energy source in some areas include the state of Victoria, contributing to over $85 \%$ of the state's electricity supply.[2] While it is abundant, this coal has low grade and high moisture content $(>45 \%)$ makes it a poor competitor to black coal. The high moisture content needs a larger sized boiler, and as a consequence, the capital, operation, and maintenance costs of lignite coal boilers are much higher than anthracite, bituminous and sub bituminous coal boilers [3]. Lignite coal is mainly used to produce energy for the local electricity market especially coal-fired power plant that is close to the coal mine.[4] Coal upgrading techniques including drying, liquefaction, and gasification have attracted attention as alternative ways to produce value-added low rank coal become a higher caloric value coal.[5, 6]. For example, Wang et al. showed that reducing moisture in Illinois coal from $40 \%$ to $25 \%$ resulted in a saving of the auxiliary powers such as fans and milling by $3.8 \%$.[7]

The coal reserve in Indonesia is considered very promising. Its predicted quantity is about 36 billion tons, with major deposits located in Kalimantan and Sumatera island. According to the Ministry of Energy and Mineral Resources, Indonesia's coal potential even reaches around 126 billion tons. However, around $60 \%$ is low rank coal (LRC) mainly lignite and low grade sub-bituminous. Its calorific value is below $4000 \mathrm{kcal} / \mathrm{kg}$, so it needs to be upgraded for a higher utilization at power generation units [8]. Additionally coal-fired power plants accounts for around $40 \%$ of global power generation and represents the most important source of electricity in use today. To calculate its electricity cost, two fundamental yardsticks are used for basic consideration, fixed cost and the variable cost. Fixed cost is the total capital investment includes the total direct plant cost (i.e. boiler, steam turbine, condenser, generator and auxiliary equipment etc.) and total indirect plant cost such as engineering and set-up. While variable cost mainly is operation and maintenance cost, fuel cost and distribution cost. Among the variable cost, the fuel is the largest cost at coal fired power plants. Indeed the fuel cost is not only includes coal purchase but also shipping cost from mining to coal silo at power plant [9].

Nagan Raya coal fired plant with capacity 2 x 115 MW, located on the South coast of Aceh, and so far is getting coal supply with calories of $4200 \mathrm{kcal} / \mathrm{kg}$ from Kalimantan in order to meet its boiler specification. The cost of procuring coal is too expensive because the very long haul distances which reach more than $2200 \mathrm{~km}$ by ship or barge. Other main challenging is delivery problems that are often disrupted because the waves on the West coast of Sumatra are very high, causes the coal unloading process often had long time delays. Eventually it makes the purchase price of coal from Kalimantan to be highly expensive. On the other hand, there is a domestic coal mining located next door of the power plant. However the typical calories from the neighbour mining are only $3200-3400 \mathrm{kcal} / \mathrm{kg}$. It requires coal upgrading technology to obtain coal calories of $4200 \mathrm{kcal} / \mathrm{kg}$ or

Corresponding author: zainal.arifin22@pln.co.id 
more. Therefore coal drying technology is expected to provide a reliable solution of coal supply to Nagan Raya power plant. In line with that, various low-rank coal drying techniques have been proposed and developed; some are being fully established while others are still emerging technologies. [10]

Regarding the environmental aspect, the domestic coal close to Nagan Raya power plant has low sulphur content. Domazetis et al. (2008) reported a 30\% relative reduction in $\mathrm{CO} 2 / \mathrm{MWh}$ when the moisture content of the coal was reduced from $60 \%$ to $40 \%$.[11] It can produce two benefits at once, increasing the heating value of coal and reducing greenhouse gas emissions. However, the level of moisture for dried coal highly depends on the type of applied technology. It varies from as low as nil for the hydrogenation process to $15 \%$ for briquetting and gasification processes.[12] A 30\% decrease in greenhouse gas emission is estimated by the implementation of efficient drying technologies in Victorian brown coal power stations.[13] A safe and efficient drying process from cost and energy perspectives can result in improvement of overall efficiency and cost reduction of the whole polygeneration process. [14] Hence this research discusses the utilization of domestic low rank coal through coal drying technology at Nagan Raya based on both technical and financial analysis.

\section{Nagan Raya Coal Power plant}

\subsection{Coal Specification}

Nagan Raya coal-fired power plant is one of the power generator units supplying electricity for the North Sumatra grid system which its peak load ever reached $2722 \mathrm{MW}$ in 2019. Nagan Raya installed capacity is $2 \mathrm{x}$ $115 \mathrm{MW}$. It functions as a base load power generation, because it's relatively low operating costs at the grid. Yet its operating cost is still higher than the similar one of the grid. The high operating costs mainly due to the fuel cost. Not only coal purchase itself but also coal transportation costs and cost of coal unloading. The long distance of coal transportation and its obstacle for unloading process is the main reason why operational costs are expensive. Generally the largest cost of coal-fired power plant is fuel costs; in this case coal is around $\sim 70 \%$ of the total operating costs.

Recently there is a new coal mining that is very close to Nagan Raya power plant within about $10 \sim 15 \mathrm{~km}$ distance from the coal yard. However, the domestic coal has lower calorific value than the calorific value of coal required with the power plant design. Table 1 shows the specifications of coal needed for the design boiler of power plant.
Table 1.Design coal specification

\begin{tabular}{|c|c|c|c|c|c|}
\hline \multirow{2}{*}{ Parameter } & \multicolumn{2}{|c|}{ Limitation } & \multirow{2}{*}{$\begin{array}{c}\text { Parame } \\
\text { ter }\end{array}$} & \multicolumn{2}{|c|}{ Limitation } \\
\hline & Unit & Value & & Unit & Value \\
\hline $\begin{array}{l}\text { Total } \\
\text { moisture }\end{array}$ & $\%$ & $25-35$ & Sulphur & $\begin{array}{l}\% \% \\
(\mathrm{adb})\end{array}$ & $\begin{array}{l}0,13- \\
0,2\end{array}$ \\
\hline $\begin{array}{l}\text { Inherent } \\
\text { moisture }\end{array}$ & $\%$ & $14-25$ & $\begin{array}{l}\text { Calorie } \\
\text { Value }\end{array}$ & $\begin{array}{l}\mathrm{kcal} / \\
\mathrm{kg}\end{array}$ & $\begin{array}{l}3700- \\
4300\end{array}$ \\
\hline Ash content & $\begin{array}{l}\% \\
(\mathrm{adb})\end{array}$ & $3-6$ & HGI & index & $40-65$ \\
\hline $\begin{array}{l}\text { Volatile } \\
\text { matter }\end{array}$ & $\begin{array}{l}\% \\
(\mathrm{adb})\end{array}$ & $28-40$ & $\begin{array}{l}\text { Feed } \\
\text { stock }\end{array}$ & ton $/ \mathrm{h}$ & $52-62$ \\
\hline $\begin{array}{l}\text { Fixed } \\
\text { carbon }\end{array}$ & $\begin{array}{l}\% \% \\
(\mathrm{adb})\end{array}$ & $23-41$ & Size & $\mathrm{mm}$ & $2-30$ \\
\hline
\end{tabular}

Table 2. Domestic coal specification.

\begin{tabular}{|c|c|c|c|c|c|}
\hline \multirow{2}{*}{ Parameter } & \multicolumn{2}{|c|}{ Limitation } & \multirow{2}{*}{ Parameter } & \multicolumn{2}{|c|}{ Limitation } \\
\hline & Unit & Value & & Unit & Value \\
\hline $\begin{array}{l}\text { Total } \\
\text { moisture }\end{array}$ & $\%$ & 43.2 & Sulphur & $\begin{array}{l}\% \% \\
(\mathrm{adb})\end{array}$ & 0.13 \\
\hline $\begin{array}{l}\text { Inherent } \\
\text { moisture }\end{array}$ & $\%$ & 23.48 & $\begin{array}{l}\text { Calorie } \\
\text { Value }\end{array}$ & $\begin{array}{l}\mathrm{kcal} / \mathrm{k} \\
\mathrm{g}\end{array}$ & 3457 \\
\hline $\begin{array}{l}\text { Ash } \\
\text { content }\end{array}$ & $\begin{array}{l}\% \% \\
(\mathrm{adb})\end{array}$ & 5.58 & HGI & index & 38 \\
\hline $\begin{array}{l}\text { Volatile } \\
\text { matter }\end{array}$ & $\begin{array}{l}\text { \% } \\
(\mathrm{adb})\end{array}$ & 38.79 & $\begin{array}{l}\text { Fixed } \\
\text { carbon }\end{array}$ & $\begin{array}{l}\% \% \\
(\mathrm{adb})\end{array}$ & 48.89 \\
\hline
\end{tabular}

Based on these data, a coal dryer is needed to convert the low calorific value domestic coal to be improved coal that meets the design boiler requirements.

\subsection{Types of Coal Drying}

Nowadays Nagan Raya power plant uses $4200-4400$ $\mathrm{kcal} / \mathrm{kg}$ of coal with a moisture content of $25 \%-30 \%$. Coal supply is delivered from outside the island (Kalimantan) so that raw material costs are burdened by transportation costs. In addition, transportation by barge through Jawa sea and Indonesia ocean had high risks due to bad weather and strong unpredictable waves. It causes so many times delays of coal supply to the power plant. Meanwhile utilization of domestic coal is still facing some obstacles especially its inappropriate quality (average heating value 3200-3400 kcal / kg with a moisture content of $42-45 \%$ ).

Based on a technical report from the Indonesian Technology Assessment and Application Agency (BPPT) in 2018, they were several coal drying utilizing low rank coal has been investigated. BPPT has selected those technologies for Nagan Raya power plant purpose, which are Steam Tube Dryer (STD) from Japan, Wave Coal from Canada/USA, LiMax Coal Processing (LCP) from China, STD from Finland, Upgrading Brown Coal (UBC) from Japan, Coal Flash Drying (CFD) from Indonesia, Coal Moisture Control Fluidized Bed (CMC-FB) from Japan. Furthermore they proposed Tsukishima STD, CMC-FB and Wave Coal as the most appropriate technology for Nagan Raya power plant implementation. [15] Following the report and proven well pilot project, this study chooses the CMC technology as the basis of analysis. The technology has had a demo plant in Fukuoka with a capacity of around $500-700 \mathrm{~kg} / \mathrm{h}$. On this demo plant the technology has proven and running well. 
This paper will use this pilot project test data on a market scale, assuming this technology is commercially successful. The assumptions come from the result of 70 tons/hour testing which is linear proportionally to the results of the demo plant. Based on the test report, the dried coal using the domestic local coal produces the following characteristics:

Table 3.The product of coal drying

\begin{tabular}{|l|l|l|l|l|l|}
\hline $\begin{array}{c}\text { Coal } \\
\text { Balance }\end{array}$ & In/Out & Kg/h & $\begin{array}{c}\text { TM, } \\
\mathbf{\%}\end{array}$ & $\begin{array}{c}\text { Kalori } \\
\text { (kCal/kg) } \\
\text { As } \\
\text { Received }\end{array}$ & \% \\
\hline $\begin{array}{l}\text { Coal Flow } \\
\text { (raw) }\end{array}$ & in & 705.5 & 42.1 & 3021 & $100 \%$ \\
\hline $\begin{array}{l}\text { Dried Coal } \\
\text { - B }\end{array}$ & out & 475.3 & 27.9 & 4108 & $67.4 \%$ \\
\hline $\begin{array}{l}\text { Fine Dried } \\
\text { Coal - B }\end{array}$ & out & 82.5 & $\mathrm{n} / \mathrm{a}$ & 3680 & $11.7 \%$ \\
\hline $\begin{array}{l}\text { Losses } \\
\text { (moisture) }\end{array}$ & out & 147.7 & $\mathrm{n} / \mathrm{a}$ & $\mathrm{n} / \mathrm{a}$ & $20.9 \%$ \\
\hline
\end{tabular}

Based on the testing data in Table 1II, the average heating value of dried coal is $4045 \mathrm{kCal} / \mathrm{kg}$. It means the domestic coal is technically feasible as a fuel for Nagan Raya power plant. It is estimated that all drying results can be used as fuel so that coal drying technology meets the design boiler requirements.

\section{Methodology}

The first step of analysis is calculation of technical boiler efficiency and economic efficiency of power plant. Calculation of boiler efficiency as a whole will use the input output method. While the economic side will be calculated by NPV, IRR and Payback Period.

In calculating boiler efficiency, the technical data directly from Nagan Raya power plant is needed. It should be noticed that currently the power plant operates with a Capacity Factor (CF) is about $65 \%$ or an average equal to around $2 \times 71.5 \mathrm{MW}$ output, The related following data is taken from the unit \#1 on October 10th, 2019. This power plant needs entirely around $1,000,000$ tons of coal per year.

The method of calculating investment parameters such as NPV, IRR and Payback Period by considering the technical aspects on operation condition as mentioned on Table 4. In this paper, the total investment needed for implementation a coal dryer technology will be a trade off with the losses caused by uncertainly and less secure of the existing coal supply from other island. Indeed, both advantages and advantages of the domestic coal will be investigated using a financial perspective.
Table 4.The parameters of boiler

\begin{tabular}{|l|l|l|}
\hline \multicolumn{1}{|c|}{ Parameter } & \multicolumn{1}{c|}{ Value } & \multicolumn{1}{c|}{ Unit } \\
\hline Active Power & 75.938 & $\mathrm{MW}$ \\
\hline Net. Power & 73.97 & $\mathrm{MW}$ \\
\hline Steam Header Temperature & 531 & ${ }^{0} \mathrm{C}$ \\
\hline $\begin{array}{l}\text { Steam Economizer } \\
\text { Temperature }\end{array}$ & 220 & ${ }^{0} \mathrm{C}$ \\
\hline Main Steam Pressure & 7.146 & $\mathrm{MPa}$ \\
\hline $\begin{array}{l}\text { Feedwater Economizer } \\
\text { Pressure }\end{array}$ & 7.77 & $\mathrm{MPa}$ \\
\hline Steam Flowrate & 284.052 & $\mathrm{Tons} / \mathrm{h}$ \\
\hline Coal Flowrate & 56.749 & $\mathrm{Tons} / \mathrm{h}$ \\
\hline Calorific Value & 16873 & $\mathrm{~kJ} / \mathrm{kg}$ \\
\hline
\end{tabular}

Boiler is one of the main equipments of power plant that converse energy from coal combustion heat energy into heat energy in form of hot or saturated steam. Such heat exchange can be formulated in the form of boiler efficiency as follows:

$\eta_{B}=\frac{\left(h_{1}-h_{2}\right) m_{m s}}{C V \times m_{e f}}$

Where :

$\eta_{\text {В }}$ : Boiler Efficiency

$\mathrm{h}_{1} \quad$ : Main steam entalphy

$\mathrm{h}_{2} \quad$ : Economizer feedwater entalphy

$\mathrm{m}_{\mathrm{ms}}$ : Main steam flowrate

$\mathrm{m}_{\mathrm{ef}}$ : Economizer feedwater flowrate

$\mathrm{CV}$ : coal calorie value

Using data from Table 4 and formula 1 , it can be calculated that the boiler efficiency is $76.06 \%$. By a simulated calculation it is known that for the change in calorie value of coal, it turns out there is a change in enthalpy of main steam $\left(\mathrm{h}_{1}\right)$ to the change in enthalpy of feed water $\left(h_{2}\right)$ or if $h_{1}$ is higher, the main steam flow rate is greater, while the consumption of fuel is lower. So it can be concluded that the boiler efficiency will be better if the ratio of steam flow to coal consumption reach a certain number.

Referring to the formula, the electricity production will be less by using the lower calorific value of domestic coal without modifications. More over to produce the same power output with different calorific value needs more flow rate of coal. However, changes in coal flow rate is limited by the size of the boiler and the capacity of supporting equipment. It means the only effective way for utilization the domestic coal with its performance is equal or better than the existing one is coal drying technology implementation.

\section{Result And Discussion}

The main point of financial analysis is to calculate the price difference between the existing used coal and the domestic low rank coal. From that, the maximum benefits is expected to cover all investment needed for coal drying 
technology installation. It can be concluded whether the coal drying project is feasible or not.

Then some assumptions used for basic calculations. Losses from the drying of coal only reduce the total moisture, based on the data in Table 3 is estimated $20.9 \%$. The gap between the price of the existing coal and the domestic low rank one is assumed constant during the calculation period. Power plant efficiency is considered not significantly changing between using the domestic coal and the existing one. The margin obtained from investors is $11 \%$. The assumption of depreciation is USD 5 /ton and OPEX of USD 6.4 /ton for 15 years.

The price of coal is based on the Argus/Coalindo Indonesia Coal Index table, November 2019. The price of raw material before coal dryingis USD 21.19 /ton. The price of dried coal is same as the price of the existing coal with the similar characteristics which is around USD 57 /ton. The volume of coal output or dried coal is decreasing by an average of $20.9 \%$ of the input coal volume.

With the above assumptions and using a common financial model calculation, an NPV of USD 43.64 million will be obtained in the 15 th year if the initial investment is USD 75 million (based on BPPT report). The IRR of the project is expected $20.67 \%$ with a Pay back Period of 6.65 years.

For the case of Nagan Raya power plant there are two main considerations related to the need for implementing coal drying; the first is the coal supply security issue and the second is the high cost of transportation includes unloading of coal on site. If there is only supply security reason which is no cost reduction after coal drying, then the maximum investment from a coal dryer can be calculated. Assuming an $11 \%$ return to investors and $\mathrm{NPV}=0$ in the 15 th year, the maximum investment cost is USD 118.65 million.

Instead of capital (CAPEX) and operational expenditure (OPEX), other determinant factor of coal drying implementation at Nagan Raya power plant is Margin Output-Input Coal (USD/ton); the difference price between the dried coal and wet coal input. In adequate margins when the low dried coal (output) prices is only enough to cover OPEX + depreciation costs, result in a pay back period of more than 15 years and a negative IRR (not feasible). Considering the margin is highly affected by how much savings of fuel costs we want to achieve, then the following simulations taking into account the variation of the price of the dried coal (output) compared to the price of coal (landed cost) at the Nagan Raya power plant. The price of landed cost is currently IDR $850,000 /$ ton or USD $60.71 /$ ton. Assuming the price of domestic coal is USD 21.19 /ton, CAPEX USD 60 million, Depreciation USD 4 /ton and OPEX USD 6.4 /ton, then the financial model is implemented with 6 scenarios of fuel cost saving $(0 \%, 10 \%, 15 \%, 20 \%$, $25 \%$ and $30 \%$ ) as Table 5.
Table 5.The Financial Analysis

\begin{tabular}{|c|c|c|c|c|c|c|}
\hline $\begin{array}{l}\mathrm{N} \\
\mathrm{o}\end{array}$ & $\begin{array}{l}\text { Coal } \\
\text { Input } \\
\text { (USD } \\
\text { / ton) }\end{array}$ & $\begin{array}{l}\text { Coal } \\
\text { Output } \\
\text { (USD/ } \\
\text { ton) } \\
\text { (dried } \\
\text { coal) }\end{array}$ & $\begin{array}{l}\text { Margin } \\
\text { Output- } \\
\text { Input } \\
\text { Coal } \\
\text { (USD/t } \\
\text { on) }\end{array}$ & $\begin{array}{l}\text { Payback } \\
\text { period } \\
\text { (y(year), } \\
\text { m(month } \\
\text { )) }\end{array}$ & $\begin{array}{l}\text { IRR } \\
(\%)\end{array}$ & $\begin{array}{l}\text { Fuel } \\
\text { Cost } \\
\text { Saving } \\
(\%)\end{array}$ \\
\hline 1 & 21.19 & 60.71 & 39.52 & 2 y $2 \mathrm{~m}$ & 50.65 & 0 \\
\hline 2 & 21.19 & 54.64 & 33.45 & 2 y $8 \mathrm{~m}$ & 40.27 & 10 \\
\hline 3 & 21.19 & 51.61 & 30.42 & 3 y $1 \mathrm{~m}$ & 34.96 & 15 \\
\hline 4 & 21.19 & 48.57 & 27.38 & 3 y $8 \mathrm{~m}$ & 29.51 & 20 \\
\hline 5 & 21.19 & 45.54 & 24.35 & 4 y $5 \mathrm{~m}$ & 23.82 & 25 \\
\hline 6 & 21.19 & 42.50 & 21.31 & 5 y $9 \mathrm{~m}$ & 17.70 & 30 \\
\hline
\end{tabular}

Based on the Table 5, the margin output is directly proportional to the IRR value but inversely proportional to the fuel cost saving and payback period. It means the level of electricity cost decrease will affect significantly the feasibility of the coal drying project. There is trade off between the cost saving with the IRR of project; the amount of electricity cost reduction desired by the utility company will reduce the profits of this project for the investor. However, the calculation shows encouraging results that with a fuel cost saving of $30 \%$ or equal to the electricity cost reduction cost of $21 \%$, the IRR is $17.7 \%$. It indicates that the coal drying technology implementation is still financially feasible and profitable for investors.

\section{Conclusion}

Due to less reliable of coal supply and the high cost of its transportation includes unloading of coal on site, the need for coal dryer in Nagan Raya power plant is very urgent. With an investment cost USD 75 million, interest rate of $11 \%$, and IRR of $20.67 \%$, the coal dryer project for Nagan Raya power plant is financially feasible. Other calculation based on investment cost of USD 60 million with several fuel cost saving scenarios, shows that the production cost of electricity can be reduced of $21 \%$ with IRR is $17.7 \%$. The coal drying technology implementation can decrease the electricity cost production for the utility and also make benefits for the investor. Further research is recommended to investigate other proven technologies instead of CMC-FB. Additionally the effect of coal drying implementation to the surrounding environment should be noticed.

\section{References}

1. B. Z. Dai, L.; Cui, J.-f.; Hoadley, A.; Zhang, L., Integration of pyrolysis and entrained-bed gasification for the production of chemicals from Victorian brown coal-Process simulation and exergy analysis. Fuel Process. ,Technol, pp. 21-31. (2017)

2. T. S. Hosseini, C.; Haque, N.; Zhang, L., Indirect carbonation of Victorian brown coal flyash for $\mathrm{CO} 2$ 
sequestration: Multiple-cycle leaching-carbonation and magnesium leaching kinetic modeling.,Energy Fuels, vol. 28(10), pp. 6481-6493. (2014)

3. H. Z. Yan, D., Modeling of a low temperature pyrolysis process using ASPEN PLUS., Dev. Chem. Eng. Miner. Process., vol. 7, pp. 577-591.(1999)

4. Q. F. Yi, J.; Lu, B.; Deng, J.; Yu, C.; Li, W., Energy evaluation for lignite pyrolysis by solid heat carrier coupled with gasification.,Energy Fuels, vol. 27, pp. 4523-4533.(2013)

5. L. E. I. Taba, M. F.; Daud, W. A. M. W.; Chakrabarti, M. H., The effect of temperature on various parameters in coal, biomass and CO-gasification: a review., Renewable Sustainable Energy, vol. 16, pp. 5584-5596.(2012)

6. C. S. Song, A.; Yoneyama, Y., A new process for catalytic liquefaction of coal using dispersed MoS 2 catalyst generated in situ with added H 2 O., Fuel 2000, vol. 79, pp. 249-261.(2000)

7. W.-C. Wang, Laboratory investigation of drying process of Illinois coals., Powder Technol. , vol. 225, pp. 72-85, 2012.(2012)

8. BPPT, Assistance and making a feasibility study on coal up grading technology for the Nagan Raya Powerplant., Final Report.(2019)

9. Ravinder Kumar, Avdhesh Kr. Sharma, P. C. Tewari, "Costanalysis of a coal-fired power plant using the NPV method', Springerlink.com. DOI 10.1007/s40092-015-0116-8.(2015)

10. M. Z. Karthikeyan, W.; Mujumdar, A. S., Low-rank coal drying technologies - current status and new
developments.,DryingTechnol. , vol. 3, pp. 403415.(2019)

11. E. Z. Binner, L.; Li, C.-Z.; Bhattacharya, S., In-situ observation of the combustion of air-dried and wet Victorian browncoal. ,Proc. Combust. Inst., vol. 2, pp. 1739-1746. (2011)

12. G. B. Domazetis, P.; James, B. D.; Glaisher, R., Treatments of low rank coals for improved power generation and reduction in Green house gas emissions. , Fuel Process. Technol.vol. 3, pp. 249261.(2008)

13. William G. Sullivan, WicksElin M., Luxhoj James T., Engineering Economy., 3th. Pearson International Edition.(2006)

14. S. V. K. Jangam, M.; Mujumdar, A., "A critical assessment of industrial coal drying technologies: Role of energy, emissions, risk and sustainability. ," DryingTechnol. , vol. 4, pp. 395-407.(2011)

15. BPPT, "Technology Selection of Coal Drying Technology for Nagan Raya Power plant," Final Report.(2018) 